Philipp Korom*

\title{
Austria Inc. Forever? On the Stability of a Coordinated Corporate Network in Times of Privatization and Internationalization
}

\begin{abstract}
One of the features of organized Austrian capitalism is a tightly-knit corporate network (Austria Inc.) that facilitates control and coordination between companies. In the 1980s the subsidiaries of the Austrian industry-holding stock company (ÖIAG) and the largest banks were the central hubs of this network. Now, 30 years later, ÖIAG has privatized nearly all its companies and banks have not only merged and sold their equity interests, but also partly joined international business groups. Nevertheless, Austria Inc. has not eroded. By analyzing a network of personal connections between 1976 and 2000, I investigate in this article how the network has reconfigured to allow Austria Inc. to perpetuate. The analysis suggests three explanations: Despite extensive privatization of the economy, Austrian ownership continues to prevail within the network; the banking group Raiffeisen filled the gap that was opened by the withdrawal of the state from the economic sphere; members of the Austrian elite still use board meetings for social networking.
\end{abstract}

Keywords: Austria; corporate network; interlocking directorates; coordinated capitalism; business elite.

\footnotetext{
*Corresponding author: Philipp Korom, Department of Sociology, University Graz, Austria, e-mail: philipp.korom@uni-graz.at
}

\section{Introduction}

Even more than the European countries Switzerland, the Netherlands, or Germany, Austria is portrayed in the literature as a concordance democracy (Lehmbruch 1969) characterized by the near absence of market-based competition and the incorporation of the major economic interest groups into the political system ("Austrian Social Partnership"). Based on relational or incomplete contracting and network monitoring, this system of co-operation is said to conciliate economic interests between companies (Hall 2006: p. 184). Especially the Variety of Capitalism (VoC) approach (Hall and Soskice 2001) postulates that coordinated market economies (CMEs), such as that in Austria, coordinate their 
activities within the areas of corporate governance, vocational training, industrial and interfirm relations more than liberal market economies (LMEs).

Research in this area has already established that corporate networks improve the collective capacity of economies for self-regulation (Windolf and Nollert 2001). Furthermore Windolf and Beyer (1995) postulated that if corporate linkages constitute a key element of the institutional infrastructure of markets, then differences between competitive capitalism, best exemplified in Europe by Britain, and cooperative capitalism, best exemplified by Germany, should become apparent in divergent network configurations. In 2002, Windolf (2002) empirically determined how the structure of corporate networks and the associated chances of cooperations differ between types of capitalism: In CMEs companies interlock to such an extent that there are dense networks of capital participation and interlocking directorates, which favor cooperation among members. In contrast, in LMEs capital and personal linkages are decoupled, and the decentralized and fragmented networks tend to be more competitive.

These very different network configurations stem primarily from two disciplinary mechanisms installed to control managers who run the day-to-day affairs of firms (Berle and Means 1948). In the instance of concentrated ownership, the balance of power is in favor of owners (of mostly parent companies) who are able to exercise network control over the management (in subsidiary companies). In liberal capitalism, corporations are in diffuse ownership without any majority investors. Here, the market's "invisible hand" controls the management. Undoubtedly the governance of Austria's companies is more network- than market-based (Stokman et al. 1985). And there may currently be no other country in Western Europe that mandates a corporate network with more resources for patient capital (Culpepper 2011). It is this strong network base that suggests not primarily investigating if Anglo-American governance principles are gaining acceptance in Austria but focusing instead on the corporate restructuring that has enabled the Austrian network solution to corporate governance problems to perpetuate. And since domestic observers seem to agree on the diagnosis of “institutional stability" (Traxler 2007: p. 41), this article is primarily concerned not with institutional change but with institutional continuity.

The enduring salience of the Austrian corporate networks, however, should not be taken for granted. In the late 1970s and 1980s, the point of departure of this study, Austria was a party-state with one of the largest public sectors in Western Europe. As if the network was almost purposefully designed, network visualizations by Ziegler (1984) show systematic interconnections between the spheres of influence of the Austrian industry holding stock corporation (ÖIAG) and those of the large nationalized banks. Now, over 30 years later, the majority of stateowned enterprises (SOEs) have been privatized, the consolidation and merger 
activity has increased significantly within the banking sectors, bank-industry relations have come to an end, and international actors have joined the Austrian corporate network. However, the national control over export-orientated companies is still in place, and the disentanglement of the network has not seemed to gather further pace but rather to continue in a piecemeal fashion. Furthermore, the exit option of minority stakeholders is not a major concern in the realm of corporate governance. This apparent continuation of the network base raises two questions the article aims to answer: Which network reconfigurations explain such an institutional stability despite major structural breaks? Which actors have filled the vacuum that remained after large scale-privatizations?

This contribution consists of three main parts. Part 1 starts by depicting how the Austrian corporate network (Austria Inc. in short) was initially configured and thus shows the interlocking directorates within the Austrian economy in the 1970s and 1980s. It then proceeds with a subsection on critical junctures ${ }^{1}$ in the development of Austria Inc.

Part 2 presents results from a longitudinal network study. For different points in time (1976, 2000-2008) the (changing) configuration of the network is studied on the basis of various types of network measures.

Part 3 ends the article by reviewing all explanations for the persistency of the network that can be substantiated by network data.

\section{The Historical Evolution of Austria Inc.}

\subsection{The Early Stages of Austria Inc.}

From the outset, the Austrian corporate network was marked by the predominance of the state as a shareholder. Even in the wake of the world economic crisis of 1929, Creditanstalt, the largest Austrian bank, had to be bailed out by the government that was itself on the brink of insolvency. By passing two nationalization acts (1946/1947), the authorities established a legal claim on banks and industries that generated 25\% of the gross domestic product (Aiginger 1999: p. 3). The first act nationalized 70 companies, including three financial institutions that had a stake in 61 other industrial companies and in ten smaller banks (Turnheim 2009).

1 Collier and Collier (1991: p. 27) define a critical juncture as "a period of significant change, which typically occurs in distinct ways in different countries (or in other untis of analysis), and which is hypothesized to produce distinct legacies." 
The second act, in 1947, placed all power facilities under state control. By 1975, 120,000 people, $19 \%$ of the workforce, were employed in industrial enterprises led by this ÖIAG group (Nowotny 1982). By the mid-1980s, Austria held by far the largest public sector in Western Europe. This extensive "austrification" was mainly due to a legal and political dilemma. In accordance with the Potsdam Agreement (1945), German assets in Austria should go to the Allied Powers. All post-war governments agreed that since the presence of foreign companies within the pre-war Austrian market had allowed unemployment to escalate, the only way to achieve the desired full employment was to nationalize on a large scale (Weber 1994).

Until the 1980s, the so-called socialized sector of the industry (Verstaatlichte Industrie) was made up of three major parts: The ÖIAG acting as a trustee for the interests of the Republic of Austria, the nationalized banks Creditanstalt and Länderbank and their industrial holdings, and the electricity sector.

In the 1980s, the sociologist Rolf Ziegler was the first to approach the emergence of "Austria Inc." from a network perspective (Ziegler 1984, 1987; Ziegler et al. 1985). At about the same time, Morawetz (1985) conducted research on interlocking directorates between nine banks and 70 industrial enterprises with the highest turnover. They were investigating what kind of network structures emerged from the fact that managers held at least two directorships. The following summarizes the most central results:

The Austrian network appears to have been designed on the drawing board. [...]. In Austria the two nationalized banks, the state-owned holding company ÖIAG and - to a lesser extent - the largest private financial institute determine the founding structure of the network by board interlocking of executive directors. Especially the two nationalized banks seem to act according to the principle "divide et impera." The integration of these relatively highly segmented spheres is due to the existence of two meeting points: the joint undertaking of the three major Austrian banks, the Österreichische Kontrollbank AG [...] A second common meeting place is Elin [a long-established Austrian electrical engineering firm], which at the time (1976), was already forced to take out banks loans (Ziegler 1984: pp. 596-597, transl. by $\mathrm{PhK})$.

This clear-cut corporate structure was to be significantly transformed in subsequent years. The next section highlights the most outstanding developments.

\subsection{A Path Analysis of Austria Inc.}

The transformations of Austria Inc. resulted primarily from the extent and chosen mode of privatization. Following the international trend, extensive privatization measures started to be supported in Austria from the 1980s onwards. This change 
in the deficit-ridden enterprises from public to private ownership was mainly triggered by the crisis of the nationalized industry. "Due to international developments - the world-wide industry-crisis in the iron and steel sector [...] failed diversifications, permanent political interventions in favor of employment security and diminishing competitiveness" (Kriechbaumer 2008: p. 370), the nationalized industry had turned into a subsidy recipient of the federal state. However, it was not only this crisis that caused political winds to shift in the second half of the "Kreisky era". ${ }^{2}$ Belke and Schneider (2006) enumerate further factors that provided impetus for privatization: the incentive to bump up the government budget, lobbying from national and especially international investment banks, an increasing general acceptance of the idea "more private, less state" accompanied by an awakening interest of all political parties in privatization.

Following Franz Vranitzky's election as chancellor in 1986, his party, the Social Democratic Party of Austria (SPÖ), argued that privatization had become a pragmatic necessity and should not be ideologically driven (Meth-Cohn and Müller 1994). Ever since, parts of the Austria People’s Party (ÖVP) have also called for privatization (Müller 1988). This cry came especially from the ÖVP business wing, which mainly consisted of managers of small and medium-sized enterprises who used to compete with the public sector. Thus, not surprisingly, denationalization of the Austrian industry continued to be pushed by the ÖVP party executive and Federal Chancellor (2000-2007), Wolfgang Schüssel (Obinger 2006). Between 2000 and 2003 a first wave of privatization was set off by the state's sale of $35.7 \%$ of VA Stahl AG, 24\% of VA Technologie AG, 25\% of Böhler Uddeholm AG, 41.1\% of Austria Tabak AG, 17.38\% of the Vienna airport, 22.4\% of the largest communication company Telekom Austria and 39\% of the public postal operator Post AG. The second wave (2004-2009) brought about a full privatization of two major steel production plants, Voestalpine AG and VA Tech AG. And in 2008, the Austrian majority state-held airline, Austrian Airlines, was taken over by the German carrier Lufthansa.

Today, it is fair to say that national industry belongs to Austria's past (Turnheim 2009: p. 121). In 2009 the ÖIAG annual report mentions only four companies with state participation: the gas company OMV (31.5\%), Post AG (52.85\%), Telekom Austria AG (28.42\%) and the mining company GKB-Bergbau $\mathrm{GmbH}(100 \%)$.

Considering the fact that SOEs formed the backbone of Austria Inc. (Ziegler et al. 1985), one may assume that the network structures portrayed by Rolf Ziegler

2 Bruno Kreisky served as a chancellor from 1970 to 1983 . He is commonly referred to as one of the country's greatest statesmen of the postwar period. 
have meanwhile eroded completely. After all, relations between nationalized banks and industries and company networks within the ÖIAG group were pivotal to the centralized network structure. We have here a sociological puzzle that needs solving: How is it that privatizations and the end of banks' participation in industrial companies have not yet made the network collapse?

This question is solved to a certain extent if one considers that decision makers were worried about the vulnerability (Katzenstein 1985) of a liberalized economy. Since the state considered it of paramount importance that property rights should not be transferred entirely to foreign investors, certain (legal) measures in favor of national shareholders were set that have stabilized the network structure over time. ${ }^{3}$ First of all, the ÖIAG's public mandate to privatize was made dependent on core shareholders remaining, if economically reasonable, national. Second, the public holding group ÖIAG, and therefore indirectly the Republic of Austria, retained between 24 and 30\% of interest in companies such as VA-Tech AG and VA-Stahl AG. The state did not completely divest of these companies until quite late in international comparison. In other companies the state has remained co-proprietor or majority shareholder. Third, in the cases of the largest and strategically most important SOEs, coalitions of national shareholders were formed in order to prevent the "selling of family silver" as public talk had it (Die Presse, 18.05.2008).

The subsequent section considers the most relevant cases demonstrating the importance attached to continued national control over large (privatized) corporations.

\subsubsection{Austria's "steel solution" - The Case of Voestalpine AG}

In 2003 full privatization was envisaged for Voestalpine AG (United Austrian Iron and Steel Works). Under great secrecy, the executive board of ÖIAG met Canadian managers to hammer out a strategy for selling majority shares with investment bank JP Morgan as mediator to the global automotive supplier Magna (in Canada).

After a public outcry, politicians changed track and came up with an "Austrian solution.” The influential governor of Upper Austria, Josef Pühringer (ÖVP), decided on a State Parliament resolution guaranteeing that Voestalpine should stay under the control not only of Austrians but of Upper Austrians (Der Standard,

3 In all privatization laws a clause was included that asked the ÖIAG to "maintain decisionmaking headquarters of the company to be privatized in Austria if possible through the creation of Austrian core shareholder structures." 
27.08.2003). In September of the same year, the cabinet assembly (Ministerrat) voted in favor of a kind of "national preference clause" (Leisch 2004: p. 49). Instead of organizing road shows to attract international investors, the Chancellor Wolfgang Schüssel and the Finance Minister Karl-Heinz Grasser opted for private hearings with a group of local investors headed by Ludwig Scharinger, CEO of the Raiffeisenlandesbank OÖ, the strongest regional bank of Upper Austria. Today, RLB OÖ and the Linz-based financial institute Oberbank are the principal shareholders of Voestalpine AG.

Reflecting on the privatization history of the firm The Economist (04.09.2003) concluded: "Mr. Schüssel, who talks fondly of open borders and free markets, now sounds happy to accept a much lower price for Voestalpine to keep it in familiar hands."

\subsubsection{Austria's “electricity solution” - The Case of Verbund AG}

According to the Nationalization Acts, public authorities have to hold the majority of shares (at least 51\%) in Austria's leading electricity company, Verbund AG, as well as in nine provincial provider companies. Most of these smaller providers, such as TIWAG, Wienstrom and EVN, also acquired shares in Verbund AG forming reciprocal cliques. This is also why a majority shareholding by the state would continue to exist even if the share capital held by the Central Government (and not the State Government) was reduced.

At regular intervals, the press speculates about planned privatizations of the public electricity sector (Die Presse, 19.06.2008). Government has, however, not yet announced any concrete deregulatory plans relating to ownership in the power sector.

\subsubsection{OMV AG, Telekom AG, Post AG - Former SOEs and now ÖIAG Subsidiaries}

ÖIAG, Austria's state holding company, has a dual mandate: Overseeing the privatization process and managing the public's stakes. This mandate holds especially in the publically listed companies OMV, Telekom Austria and Post Austria "representing some $€ 25$ billion worth of turnover with a total staff of more than 100,000 (4\% of employees in the business sector)" (OECD 2003: p. 59). Furthermore, it is considered to be some kind of buffer in case of political interference (from ministries). 
The oil and chemicals group OMV is Austria's largest industrial company and one of the leading economic actors in Central and Eastern Europe (CEE). It was the first ÖIAG subsidiary to be listed in the stock exchange. Initially, state interests in OMV amounted to $72.25 \%$. Today ÖIAG is still the core shareholder, holding 31.5\% equity stake within an "augmented stakeholder coalition" (Vitols 2004) that includes pro-shareholder value institutional investors. This mix of interests has proved to be successful: "OMV has been continuously paying dividends since 1994 that filled the coffers of ÖIAG” (Die Presse, 12.07.2009).

The "Telekom affair," is one of many corruption scandals that has rocked Austria recently and revealed almost a tradition of doing business and politics through personal connections and favors. In this affair, the former Minister of Infrastructure, Hubert Gorbach, was suspected, among other things, of receiving $€ 264,000$ for adapting laws according to Telekom Austria's wishes.

Despite many suspicions of bribery and money laundering, moral outrage, and a president calling for a "clean hands" policy, public ownership of OMV, Telekom and Post Austria has not yet been called into question. It was only recently reported that partial privatization of the "Big Three" would yield estimated profits of about one billion Euros (Böheim et al. 2010).

\subsubsection{The Realignment of the Banking Sector - Consolidation and Internationalization}

The changing contours of Austria Inc. resulted not only from privatizations but also from major structural breaks within the banking sector. Banks have always been the linchpin of the corporate network. In the First Nationalization Act, the Republic of Austria was declared sole owner of three major banks, Creditanstalt-Bankverein (CA-BV), Länderbank and Österreichisches Creditinstitut. Especially CA-BV functioned as an ultimate parent company "that owned at least one company in each branch of industry. In industrial financing CA-BV and Länderbank dominated the scene" (Chaloupek and Jetschgo 2004: p. 118). It was these financial institutions that received public capital injections to compensate for loan defaults in their industrial subsidiaries, which again was a way of securing employment. Moreover, because of a state guarantee, these banks could raise credit under favorable conditions usually only granted to clients who fulfill the highest creditworthiness standards. As far as bank-industry relations in Austria are concerned, interlocking directorates served especially banks' control in capital-intensive companies: By having their representatives on the supervisory boards, banks signaled to potential investors that they were in a position to control any moral hazard that may arise. 
The 1990s brought a fundamental restructuring of the finance sector. To stay competitive in a single EU banking market with no entry barriers, the banking sector was forced to consolidate. Additionally, Austrian banks were among the first to invest in Central and Eastern European countries. This consolidation and the expansion to Central and Eastern Europe brought with them some consequential structural changes, summarized briefly below.

In 1991 Bank Austria emerged from a fusion of Zentralsparkasse and Länderbank. In 1997, at the end of Creditanstalt-Banverein's privatization, which had been protracted by political interventions (Grubelnik 1998: pp. 193-258), a structural change rocked the finance sector: Bank Austria acquired CreditanstaltBankverein, and thus the finance institute with the longest standing tradition. Bank Austria Creditanstalt was then taken over by Germany's Hypovereinsbank (HVB Group) in 2000, which in turn was absorbed by Italy’s UniCredit.

Additionally, Bank Austria gained from Creditanstalt and Länderbank industrial participations (e.g., Lenzing, Semperit, A. Porr) that were systematically outsourced (Bruckner and Stickler 2000: p. 139) as the bank moved from relationship to transaction-oriented banking. Earlier, Bank Austria had already sold its interests in smaller Austrian saving banks (Sparkassen) and especially in its controlling institution Girocredit. Die Erste Bank was subrogated into all rights and obligations of GiroCredit in 1997 and today coordinates all locally-anchored savings banks, which have started to incorporate their banking operations (mostly lending) into a savings bank stock corporation.

If one considers that pre-Second-World-War Austria was described by historians as a "one-bank system" (Teichova 1994: p. 8) with the giant Creditanstalt, the death of the bank and its many credits-led bank-industry relations have to be considered as the most fundamental ownership changes within the corporate network.

Another restructuring phase started when Österreichische Postsparkasse and Bank Austria Bank for Labour and Economy (BAWAG) merged in 2005. Later on, the US Fund Cerberus bought BAWAG, an institute that had been owned for its near century of existence by the Austrian Federation of Trade Unions (ÖGB). The links between the socialist-led union and the bank were cut when losses that came from a series of failed bets using risky derivative investments held in offbalance-sheet vehicles were made public.

From the 1990s onwards, Austrian banks such as Erste Bank, Raiffeisen Bank, and Bank Austria invested heavily in the CEE region. Today the banks' assets in CEE amount to almost 70\% of Austrian GDP and outstanding loans in Hungary and Russia alone are estimated to be $€ 51.6$ billion (Spiegel International, 11.03.2009). 
Although this historical summary sheds some light on the strange nondeath of Austria Inc., a complete explanation of the phenomenon is still missing. Such explanations are usually process-oriented: Figurations such as Austria Inc. consist of continuous flows that may end up producing structural changes of an evolutionary nature. Reconstructing these evolutionary stages helps to deepen our understanding. One has to be aware, however, that simply identifying a genealogical order by no means automatically leads to events that are subsequent (Elias 1970).

Part 3 of this article therefore investigates the changing personal interlocking in Austrian Inc. over time. Before presenting empirical results, we must address first a relevant methodological issue: The meaning of interlocking directorates.

\section{Interlocking Directorates in Austria's Economy (1976-2008)}

\subsection{Interlocking Directorates}

Austria Inc. is constructed here by looking at interlocking directorates (ID) only. These IDs have been used as research material in the social sciences for more than a century. Even encyclopedia entries have been written on ID (Mizruchi and Marquis 2006). In German-speaking Europe, corporations (Aktiengesellschaften, AG) and companies with limited liability (Ges. mit beschränkter Haftung, GmbH) have a two-tier board structure, comprising a management (Vorstand) and a supervisory board (Aufsichtsrat). Therefore, two manifestations of ID can be identified: If a (executive) manager of corporation $A$ is a member of the supervisory board of corporation $\mathrm{B}$, one can code a directed linkage. One can speak of an undirected linkage if a person is member of the supervisory boards of the corporations A and B.

As social scientists are normally not permitted access to board meetings, data on interlocking directorates is rather weak as we do not know "what flows across the links, who decides on those flows in the light of what interests [...] in order to make sense of intercorporate relations" (Stinchombe 1990: p. 381). One of the key methodological problems is the dual character of networks of interlocking directorates. Not only is the network partly built on fairly permanent economic relations between companies (inter-organizational phenomena) but the network also results from managers accumulating directorships to maximize their individual reputation (intra-class phenomena). The functional approach, which postulates 
that board directors are boundary spanners linking companies with the external environment in order to extract resources for successful operations (resource dependence theory, Pfeffer and Salancik 1978), is almost diametrically opposed to elite theories claiming that directors connect through common participation on corporate boards to foster social cohesion among the capitalist class (Mills 1956). Keeping these distinct driving forces for network formation empirically apart has turned out to be barely achievable (Stokman et al. 1988).

The present study draws on a commonly accepted definition of ID as opportunity structures (Windolf 2006: p. 39) whereby ID are to be interpreted like roadmaps: By analyzing ID one can observe which "locations" are connected to each other, where "stops" can be made, and which "traffic connections" exist.

An example of the plausibility of such loose interpretations of ID is given in the roles played by Erwin Hameseder. In 2008, Erwin Hameseder was not only chairman of the management board of Raiffeisenlandesbank NiederösterreichWien AG, but also a member of supervisory boards of the food companies Agrana Bet.-AG and Leipnik-Lundenburger Invest Beteiligungs AG., the Vienna Airport, and the construction company Strabag SE. In all of these companies, the Raiffeisen bank group became a majority shareholder. On the basis of his multiple directorships, Hameseder can function simultaneously as a representative of Raiffeisen interests in these subsidiaries. In the case of Hameseder, it is more increased information availability than prestige that motivates the appointments. Both explanations, however, are compatible.

An analysis of ID as a form of social infrastructure thus allows the identification of director interlocks that have the potential to promote cooperation between companies. To avoid a sterile analysis of corporate networks, the empirical part of this article focuses on the change of structures across time and thus on the institutional stability or discontinuities within Austria Inc.

\subsection{Research Questions and Methodology}

One can only speak of the continuity of Austria Inc. if key characteristics of the initial network configuration stay unchanged over time. A first set of research questions thus refers to the development of selected specific features of Austria Inc.

\subsubsection{Multiple Directors}

In a landmark 1984 study, Michael Useem presented overwhelming evidence that directors sitting on multiple boards did not only enjoy high status and prestige 
but tended to transcend the narrow perspectives of company-specific interests and represented instead the overall interest of big business. Such directors, as for example the director general of Creditanstalt and former finance minister (19701981) Hannes Androsch, were a distinguishing mark of Austria Inc. Androsch was known to aggregate business interests and articulate them to the political system. To what extent has the number of multiple directors decreased?

\subsubsection{Cohesive Overall Network}

The label Austria Inc. stands for a tightly knit network of companies that gave managers a steering potential far beyond their companies' borders. Can we today still speak of a high-density corporate network?

\subsubsection{Cohesive Subgroups}

The common structural pattern of Austria Inc. used to be that of hierarchical nesting at low connectivity levels and non-overlapping groups at high connectivity levels. Cohesive blocks stood mostly for business groups, especially bank-centered groups of industrials around Creditantalt or Länderbank, or state ownership in the service sectors under the roof of Austria's public sector industrial holding (ÖIAG). Is the network integration still high or has the number of loosely connected companies in the network periphery increased?

A second question set is concerned with internal dynamics. If Austria Inc. turns out to be characterized by a stable macro-level network structure, then the following question arises: Which companies or business groups have substituted the state and taken over its role as a central supporting pillar of the network?

All these questions are addressed in this longitudinal study of interlocking directorates (1976-2008) in Austria's big business. The data set for the benchmark year 1976 was taken from the hitherto most comprehensive cross-country study on ID (Stokman et al.1985). The research team led by Stokman deemed a sample of the largest 200 non-financial and the “top 50" financial corporations adequate for a comparison between countries. Sampling criteria involved turnover and, for banks, balance sheet totals. The same criteria are applied in the present study. All data on the years 2000-2008 are taken from the source "company data base Austria" (Firmendatenbank Österreich) of the publishing house Hoppenstedt. Except for 2003, editions for the second half of each year were chosen. As no data were available for 2002, I resorted to the latest company information for the year 2001, which should yield reasonably accurate results for changes between 2001 and 2003. 


\section{Results}

The development of the number of multiple directors, thus the virtuosos among networkers, proves to be mostly steady over time. Table 1 clearly demonstrates that the accumulation of directorships stays outstanding throughout the time span, decreasing only slightly. In 1976, 50 managers within the group of multiple directors, $2 \%$ of all persons in the sample, accounted for $74 \%$ of all 1489 linkages between corporations (Ziegler 1987: p. 82). Likewise all registered multiple directors between 2000 and 2008 accounted for around $70 \%$ of all corporate interlocks within Austria Inc. Due to a corporate governance reform that limited the number of possible business functions to eight, there are no directors with ten or more directorships by 2008. The number of all other virtuosos stays, however, more or less the same. The overall distribution suggests that a core group of directors still influences key decisions affecting most corporations within Austria Inc. Nearly no strategic possibilities seem to be available for evading members of the "inner circle” (Useem 1984).

The macrostructure of the corporate network is marked only partly by resilience (compare Table 2). In the directed network, both the density ${ }^{4}$ and the connectivity of the network gradually decrease, following a zig-zag pattern. These parameters show a drop that reaches rock bottom in 2004 and then increases again (Table 2, rows 1-4). It is obvious that interlocks depend on the size of corporate boards. It turns out that the two-tiered board encompasses fewer members over time (row 18).

Table 1 Multiple Directors of Austria Inc. in the Years 1976, 2000 and 2008.

\begin{tabular}{lrrr}
\hline & $\begin{array}{r}1976 \\
\text { abs (\%) }\end{array}$ & $\begin{array}{r}2000 \\
\text { abs (\%) }\end{array}$ & $\begin{array}{r}\mathbf{2 0 0 8} \\
\text { abs (\%) }\end{array}$ \\
\hline $4-5$ directorships & $35(70)$ & $29(64)$ & $31(72)$ \\
6-7 directorships & $5(10)$ & $10(22)$ & $7(16)$ \\
8-9 directorships & $4(8)$ & $3(7)$ & $5(12)$ \\
10 or more directorships & $6(12)$ & $3(7)$ & $0(0)$ \\
Number of managers & $50(100)$ & $45(100)$ & $43(100)$ \\
Number of positions & 292 & 258 & 219 \\
\hline
\end{tabular}

4 Network density is defined as the ratio between the number of links between pairs of units and the number of possible connections. Density scores may vary between 0 and 1 , with higher scores reflecting networks of higher density. 


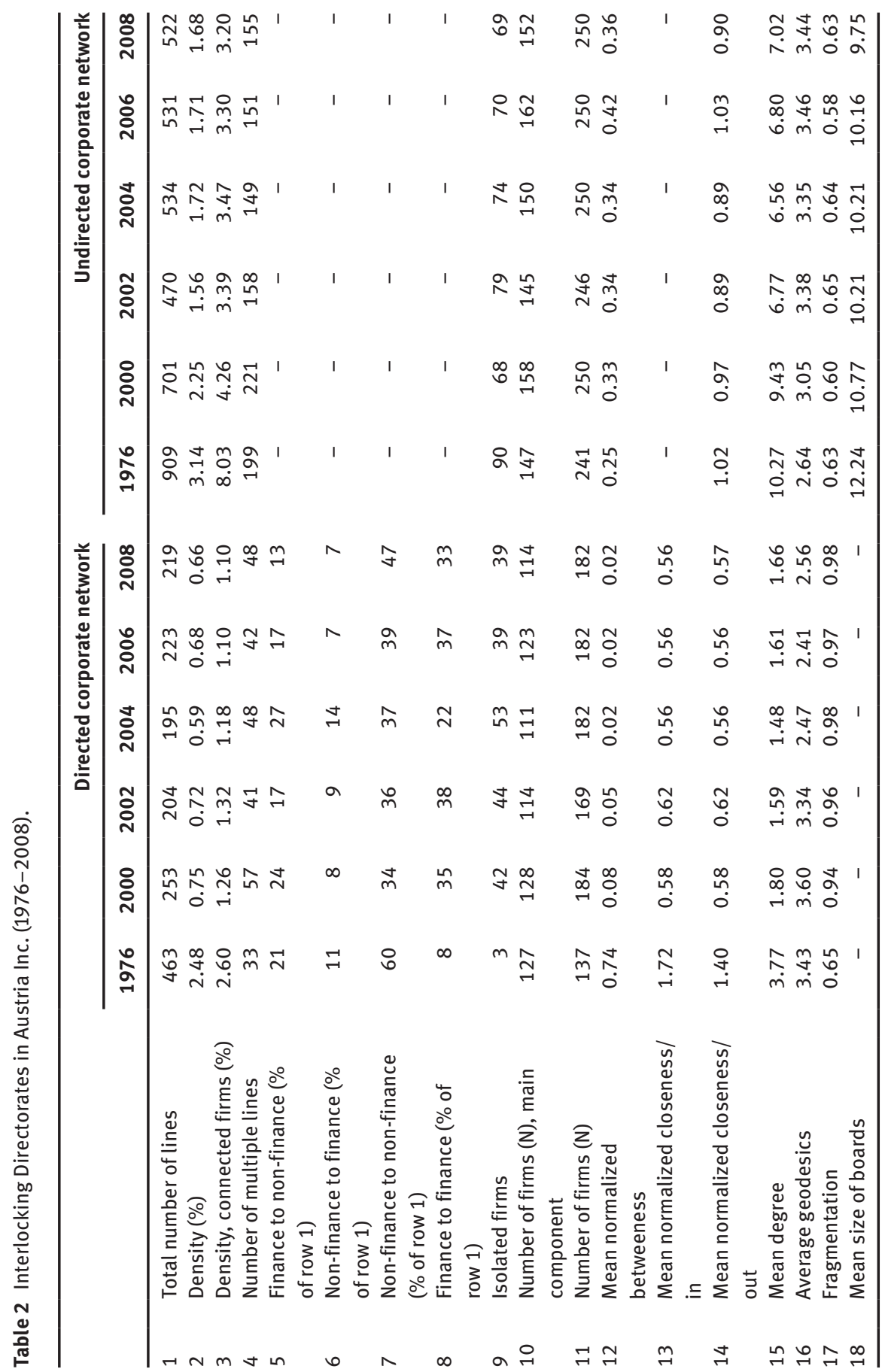


The common thread through all years is the main component ${ }^{5}$ of the network (row 10). Admittedly its size varies over time, but Austria Inc. stays organized and does not split up into separate business groups. The unity of the network is confirmed as well by the constant low scores for the fragmentation index ${ }^{6}$ (row 17).

All centrality measures ${ }^{7}$ follow a meandering trajectory, which does not point to a significant disentanglement of corporations from their interlocking directorates. The development of the average degree (row 15) shows that a corporation held on average 1.8 directed links in 2000, 1.48 in 2008 and 1.66 in 2008. Measurements for closeness- and betweeness-centrality suggest, however, only a slight decline at the beginning of the observation period.

The diameter figure (row 16) means that, at the extreme, two companies were indirectly linked through three others in almost all years. This observation can be interpreted as another sign for unaltered structural relations among large companies.

Particularly evident in Table 2 is the network erosion between 1976 and 2000. However, because of sample composition discrepancies, ${ }^{8}$ numerous mergers, and changes of company names, all results from 1976 can only serve as a rough benchmark. The fact that the change over time in interlocking directorates is far more marked between 1976 and 2000 than between 2000 and 2008 hints to stable patterns of interlocking practices in recent years. A disintegration of the network is thus not on the horizon.

A micro-level analysis (see Figure 1) that studies interlocks between and within business sectors, provides further insights into the causes of the gradual dissolution of Austria Inc. Within the finance sector (F/F), interlocking

5 "A component is a [...] subgroup having the property that its members are pairwise connected to each other, either directly or indirectly via any number (!) of intermediate steps" (Hummel and Sodeur 2010: p. 594, trans. by PhK). The main component retains all the nodes and relations among nodes that are part of the largest component of a graph.

6 The fragmentation index (Borgatti et al. 2002) measures to what extent a network is disconnected. This index ranges from zero to one; a low value indicates that the network is highly connected, and a high value means that the network is very fragmented.

7 In respect to centrality in social networks, several perspectives are possible, each relevant in its own way (Trappmann et al. 2005: pp. 25-70). Degree centrality is the simplest and most intuitive. It measures a node's centrality according to the number of connections to others, i.e., degree in undirected graphs and indegree/outdegree in directed graphs. Betweeness centrality measures the extent to which a particular point lies between the various other points in a graph. Closeness centraliy is a more global measure that brings into play the closeness to all network members, not just connections to immediate neighbors.

8 In the sample for the benchmark year, 1976 Rolf Ziegler had included 26 (instead of 50) financial corporations only. 


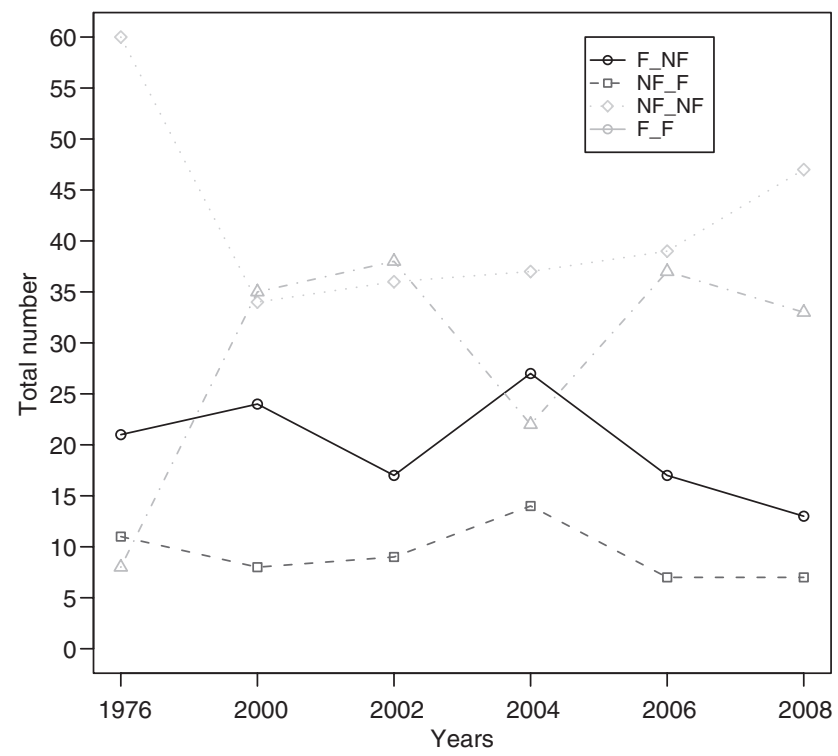

Figure 1 Types of Directed Interlocks Between Finance and Non-Finance Sectors.

directorates dropped significantly between 2002 and 2004, as clearly indicated by the downward plunge of the F/F-line. This trend was caused by the merger of Bank Austria and Creditanstalt, which made many interlocks within the finance sector redundant, as for example the multiple directorships of the Bank Austria general director Erich Hampel. Another triggering factor was a temporal drop in the interconnectedness in the savings bank sector. By 2006 the board member Elisabeth Bleyleben-Koren had already joined four supervisory boards of regional saving banks re-establishling thereby the links between the parent company (Erste Bank) and its subsidiaries. Cooperative banks tended to interlock more from 2006 onwards as well.

The Raiffeisen banking group turns out to be the stable backbone of Austria Inc. It has a three-tier cooperative organizational structure compromising 599 autonomous, locally active Raiffeisen Banks: The Raiffeisen Banks in each of Austria's nine provinces own their respective Regional Raiffeisen Bank (Landesbank), which are again coordinated by a core institution called Raiffeisen Zentralbank (RZB). Especially the linkages between the second and the third tier contribute significantly to all F/F-interlocks.

Industrial companies prove to be "islands of planned coordination in a sea of market relations” (Richardson 1972: p. 883). The mere fact that the size of the main component (Table 2, row 10) stays constant over time speaks in favor of 
the importance ascribed to inter-firm cooperations (NF/NF). The propensity for building up ties within inter-organizational networks can be inferred from theory. Pfeffer and Salancik (1978: p. 2), the leading exponents of the so-called resource dependency theory (RDT), assume that "the key to organizational survival is the ability to acquire and maintain resources.” The theory's central proposition is that organizations will interlock with each other to reduce uncertainty in the flow of needed resources from the environment. A detailed analysis reveals, however, that this axiom does not help to explain the specific structure of Austria Inc. Zooming into the network, one can see in all years ties that bridge all kind of sectors and do not seem to follow an economic rationale. A very evident example is the interconnectedness between the Austrian Railways (ÖBB) and the fruitjuice producer Rauch Fruchtsäfte in 2008 (see Figure 2) that becomes plausible in the light of elite theories only. The former financial counselor of Austria's People Party (ÖVP), Franz Rauch, was CEO of Rauch Fruchtsäfte GmbH \& Co and held several seats in supervisory boards of companies such as ÖBB Holding, ÖBB Personenverkehr (passenger transport), Rail Cargo (railway logistics), the power generation company Vorarlberger Illwerke and Bank Austria CA AG that was once indirectly state-owned. The many ties mirror the rock-solid connection of political power brokers and economic leaders in the small alpine country. Within Austria Inc., directors' interlocks thus depend, to a significant extent, on political affiliations (see for the Hungarian case: Stark and Vedres 2012).

Typical patterns of business embedding, as depictured in Figure 1, do not always contribute to coordinated decision making or help to buffer extraordinary uncertainties. In many cases, interlocks are created by politicized managers, who accumulate directorships in state-close corporations. There is much to support the assertion that the old system of mass patronage (Proporz) has given way to elite patronage (Treib 2012). Board interlocks in Austria clearly serve, among other things, as devices for elite formation and are influenced by the politics of patronage. To measure the extent of patronage in Austria Inc., however, goes far beyond the scope of this article. ${ }^{9}$ Here it should only be emphasized that the increase of NF-NF-interlocks between 2006 and 2008 does not spring from business networks only but mirrors partly cultural contingencies and shifts in elite formation.

A more satisfactory explanation can be given for changes in bank-companyrelations (F/NF, NF/F), especially for the zig-zag course of F-NF-interlocks. The downward trend is caused by the business strategy of Bank Austria CA to sell

9 For a comprehensive quantitative analysis of patronage appointments in Austrian state-owned enterprises see Ennser-Jedenastik (2013). 


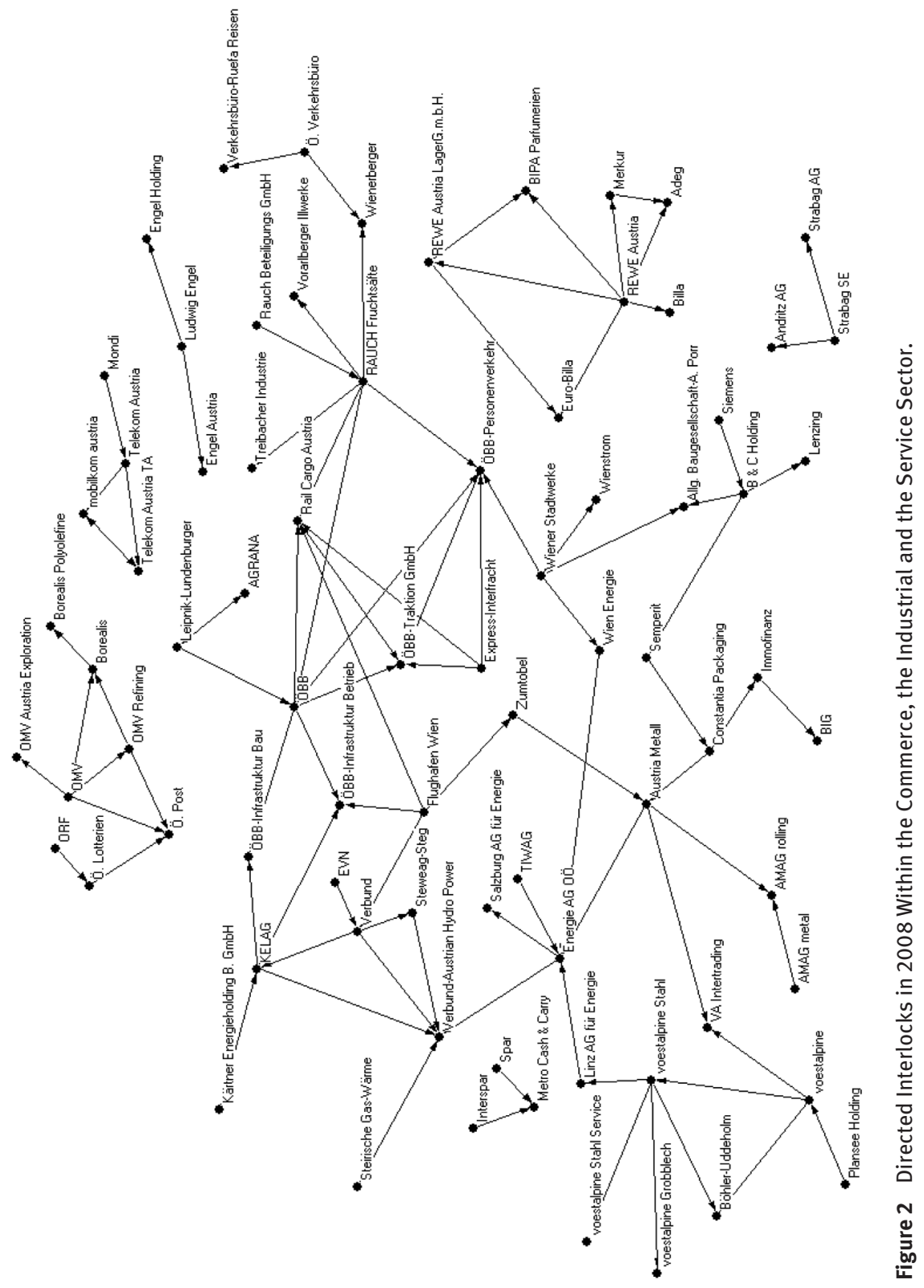


the hodge-podge of industrial participations that it inherited from Creditanstalt. Directly after the merger in 1997, Bank Austria aimed at divesting itself of its financial-industrial networks. Within one year, interests in the important metalprocessing enterprise Steyr-Daimler-Puch AG, the automobile manufacturer Fahrzeugtechnik AG (that installed equipment primarily for Daimler Chrysler), and the automotive parts producer Unitech AG were sold. By doing so, the bank generated the needed revenues to compensate for the purchase costs of taking over Creditanstalt and channeled capital into the more profitable retailing banking. In the following years, the bank continued to transfer its shareholdings. This transfer is the main reason behind the bank-industry connection (F-NF) dropping between 2000 and 2002. The rise of F-NF interlocks between 2002 and 2004 is due to the Raiffeisen banking group (RZB). RZB is today the largest holding company in Austria especially holding substantial stakes in the international construction corporation Strabag, the publishing house Kurier, and the insurance company Uniqua. In addition, the Regional Raiffeisenbank of Upper Austria (Raiffeisenlandesbank Oberösterreich AG) is deeply embedded in the local economy acting, among other things, as the house bank for the important steel producers (Voestalpine, AMAG) that emerged as rapidly growing private companies from the core of the privatized business sector. Top managers of Raiffeisen are also represented on numerous supervisory boards of today's state-owned enterprises (Austrian Lotteries, Austrian Mint, Casinos Austria).

Raiffeisen, whose precursors were the rural cooperatives in Austria, is commonly caricatured by the right-wing party FPÖ as Konrad-Giebelkreuz-Krake ${ }^{10}$ and referred to by journalists as the "green giant" (Die Zeit, 26.08.2010). All criticize the excessive accumulation of power within a single institution that is not legitimized by the people. Raffeisen's shareholding in the media sector are judged as especially alarming as they might endanger the impartiality of the press. It is safe to say that, after a period of privatization and liberalization, the financing power of Raiffeisen's many network banks is by far the most outstanding characteristic of Austria Inc.

In recent years, the most significant transformation has been the apparent power shift between growing and declining business groups. To detect these changes, I decompose networks into groups marked by multiconnectivity, which

10 (Christian) Konrad epitomized Raiffeisen and was a representative of Austria's rural catholic heritage. Konrad was a prominent promoter of pilgrimages and church restorations. The gable cross (Giebelkreuz) is the symbol of Raiffeisen representing two crossed, stylized horse heads attached to a house gable. The Freedom Party (FPÖ) mainly attacks Raiffeisen because of its close ties to Austrian People's party (ÖVP). It's many crossholding are portrayed as the tentacles of an octopus (Krake). 
usually stand for collections of collaborating firms. When I use the term multiconnectivity, I am referring to k-components, in which all nodes are k-connected (Scott 2000: p. 110). k-Components can take the form of Russian dolls with increasingly cohesive groups nested inside each other. The most common example would be a group with a highly cohesive core, surrounded by a somewhat less cohesive periphery. The more "dolls" are placed one inside the other, the higher the k-connectivity level. All components in Figure 3 are named after their most central companies. Numbers in italics stand for the connectivity level of the subgroup and numbers in bold indicate how many corporations a box encompasses. For overview purposes, interconnections between different business groups are not displayed in the figure.

For the year 1976, the chosen methodology reveals a clear picture of the corporate landscape: Besides a subgroup of Raiffeisen cooperative banks, two highly connected business groups headed by the bank Creditanstalt and the state public holding company ÖIAG dominate the scene. At that time, Creditanstalt was as much an industrial holding company as a bank. The bank's heads held directorships in scores of companies, and the bank retained a holding in shares that it had issued. ÖIAG exclusively exercised trusteeship of the shareholding rights of the Republic in nationalized industries. From the 1980s onwards, however, its activity was put on a new legal footing as it was tasked with privatizing the majority of its holdings. The consequences of privatization come to the fore in the depiction of business groups in 2000: ÖIAG has disappeared as a central actor. Instead, the former public sector has been split up into small separate groups. One of these subgroups gathers around the steel producer Voestalpine, which used to be the flagship of the state-owned industry and a quasi-fief especially of the Social Democratic Party of Austria (SPÖ). Creditanstalt was absorbed by Bank Austria, which shows up as a central building block. All other business groups clearly belong to one specific economic field and do not appoint directors to sector-external companies.

Privatizations under Federal Chancellor Wolfgang Schüssel (ÖVP) initiated the most far- reaching restructuring within Austria Inc. In 2004, the largest business group was spearheaded by the Raiffeisen Holding of Lower Austria/Vienna (Raiffeisen NÖ-Wien). The management team of Raiffeisen as a whole has wellestablished networks with such companies as Austrian Airlines, AUA, Tyrolean Airways and also Austrian Lotteries and Bank Austria CA. While Raiffeisen has gravitated more and more towards the center of Austria Inc., many business groups have declined in size or disappeared entirely from the scene. Heineken, for example, took over the Austrian brewery group Brau Beteiligungs Aktiengesellschaft (BBAG) in 2003, which led to a decline of the size of the holding of brewers in Austria (Brau Union). Such ownership un-bundlings that occured in 


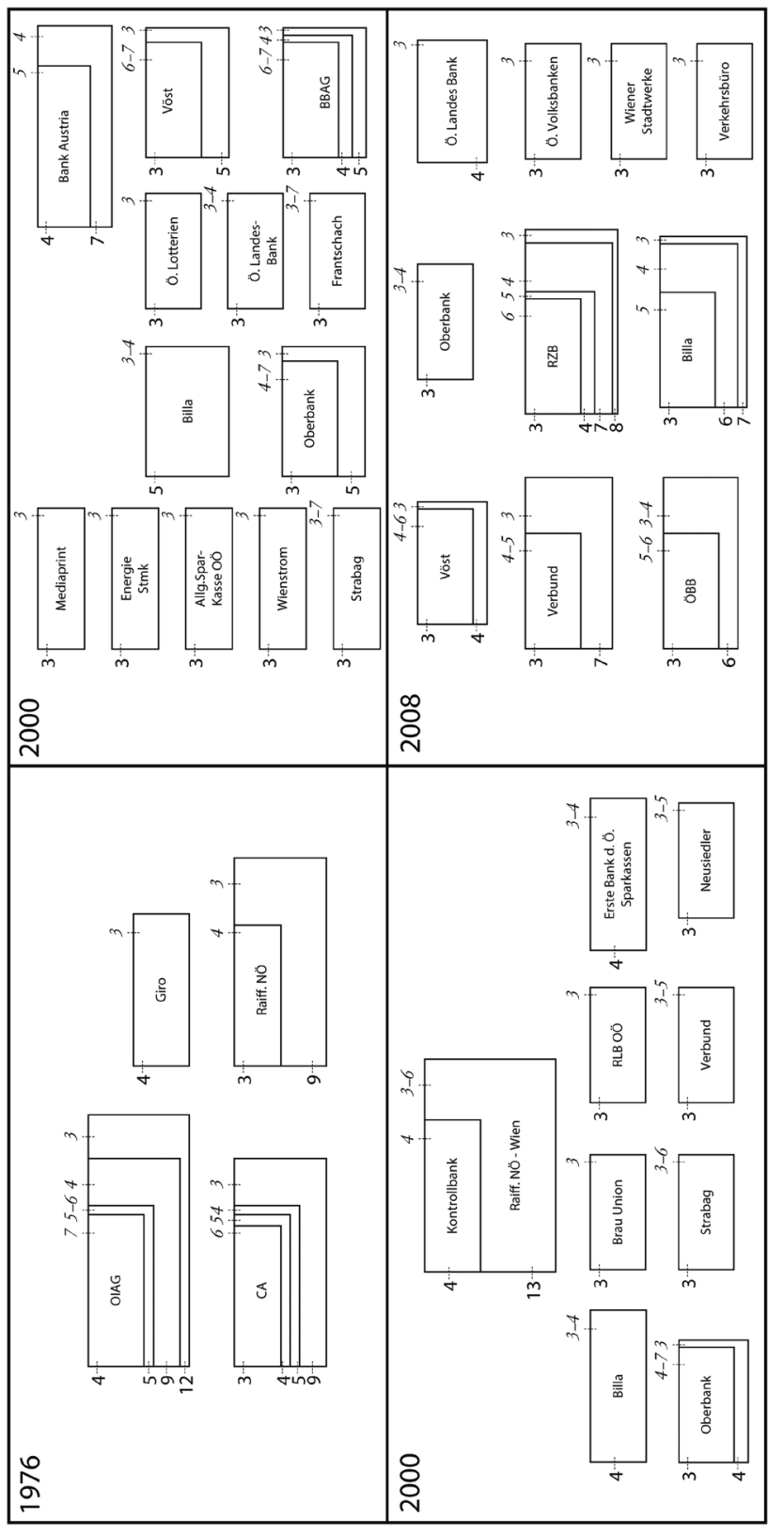

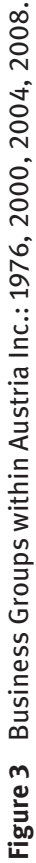


the wake of the privatizations and internationalization of Austria Inc. left their mark on the overall structure of the network (see indicators of decline in cohesion Table 2).

In 2008 a more consolidated network structure is visible. RZB (Raiffeisen Central Bank) has turned into the most central corporation in the still powerful Raiffeisen group and several (former) public-sector undertakings have built interlinkages across business sectors. The semi-public oil and gas company OMV, Telekom Austria, and the Austrian Post share three supervisory board mandates. Subsidiaries that belong either to Voestalpine, the Austrian Federal Railway ÖBB or to Austria's leading electricity company Verbund prove to be highly clustered. The (former) public sector, in brief, has disintegrated but is still represented by different business groups. Raiffeisen again occupies a central position within Austria Inc., which enables the banking group to link disparate actors in the network.

\section{Conclusions}

When one debates the decomposition of coordinated networks in Europe, the smallness of countries has to be considered as a crucial contextual variable. It seems that in Austria the intercorporate network's function as a "a protective shield" was much more pronounced than in larger European countries such as Germany (Höpner and Krempel 2004). The network was and still is an important part of the Austrian corporate governance regime, and its traditional function is still to reduce the external vulnerability.

Mainly as a result of privatizations and Europeanization, by which barriers to trade and capital flows were removed and value chains became increasingly internationalized, the traditional institutional network governance in Austria has been shaken. However, despite major signs of erosion since the 1980s, the changes have not been so profound that they might disrupt the national system. At the level of the intercorporate network, the infrastructure of coordination seems still to be in place. This article investigated which reconfigurations facilitated in perpetuating Austria Inc.

The main explanation for the persistency of the network is that despite the extensive privatization of the Austrian economy, national owners continue to prevail within the network. Privatization has been framed by politics in such a way that in most cases national majority shareholder succeeded the Republic of Austria as a shareholder. For example, with the support of the provincial government of Upper Austria, the Raiffeisen banker Ludwig Scharinger managed to keep 
the privatized giant steel producer Voestalpine in the hands of Austrian shareholders. Theorizing the corporate network in terms of "domestic compensation" (Katzenstein 1985) ${ }^{11}$ proves even to hold for the time of the most extensive privatization waves under the "small coalition" (i.e., ÖVP-FPÖ, 2000-2007), which chose as its motto "less state, more private."

It has to be added, however, that the state has not completely stepped out of its role as a shareholder. Interests in OMV, Telekom Austria, and Post Austria as well as the continued full ownership of the Austrian Federal Railway (ÖBB), the power company Verbund and its subsidiaries (i.e., Rail Cargo, Viennese power provider Wiener Stadtwerke) are important supporting pillars of today's Austrian corporate network.

The vacuum that was caused by privatization was partly filled by a new key player, the Raiffeisen bank group. Certainly Raiffeisen's scope does not come close to that of the public sector in the 1980s. It is, however, fair to say that the bank group functions as the new gravitational center of Austria Inc. It is therefore Raiffeisen managers who pull many strings in the privatized Austrian corporate network.

A micro-level analysis of interlocks between different business sectors has produced mixed results. While the decline of bank-industry networks can be interpreted as an adaption to new competition conditions, temporal increases of interlocks between non-financial corporations pose puzzles to the social scientist. Network visualizations (see Figure 2) lead one to suspect that interlocking directorates are not only used in Austria as environmental management strategies leading to uncertainty reduction and organizational effectiveness, as postulated by the resource dependence theorists (Pfeffer and Salancik 1978). Director interlocks can, to a certain extent, also reflect friendships of top corporate officers ${ }^{12}$ or personal connections between business and politics in Austria. There is firm evidence that "Proporz" (i.e., the proportional representation of ruling parties in administration and public sector) remains widespread and that a change of government still leads to political color changes in supervisory boards of large companies (Ennser-Jedenastik 2013, Korom 2013). I therefore agree with Heemskerk (2007: p. 12) that "the interpersonal and the inter-corporate network must

11 The example of the cigarette manufacturer Austria Tabak clearly demonstrated the possible harmful consequences of foreign ownership. After the state-owned company had been sold to the Gallagher Group (UK), production sites in Hainburg and Vienna were closed down and 320 employers dismissed.

12 That personal acquaintances play a major role in the recruitment of supervisory directors in state-close corporations is suggested by a recent survey conducted by the Vienna University of Economics and Business (Hoffmann et al. 2011). 
be analyzed in conjunction, if we want to understand fully the dynamics of the network of interlocking directorates."

At this stage, further investigations are warranted. Future research should investigate with greater rigor the extent to which director interlocks stem from interpersonal connections and/or political affiliations.

\section{References}

Aiginger, Karl (1999) “The Privatization Experiment in Austria,” Austrian Economic Quarterly, 4(4):261-270.

Belke, Ansgar and Friedrich Schneider (2006) "Privatization in Austria: Some Theoretical Reasons and Performance Measures." In: (Köthenbürger, Marko Hans-Werner Sinn and John Whalley, eds.) Privatization Experiences in the European Union. Cambridge, MA: MIT Press, pp. 89-116.

Berle, Adolf A. and Gardiner C. Means (1948) The Modern Corporation and Private Property, New York: Macmillan.

Böheim, Michael, Heinz Handler and Margit Schratzenstaller (2010) “Optionen einer einnahmensbasierten Budgetkonsolidierung," WIFO-Monatsberichte, 3:269-283.

Borgatti, Steve P., Everett G. Martin and Lin C. Freeman (2002) Ucinet for Windows: Software for Social Network Analysis. Harvard, MA: Analytic Technologies.

Bruckner, Bernulf and Rudolf Stickler (2000) Österreichs Bankwirtschaft. Struktur, Wirtschaftlichkeit und internationaler Vergleich. Wien: Orac.

Chaloupek, Günther and Johannes Jetschgo (2004) Österreichische Industriegeschichte 1848-1955. Die verpasste Chance. Wien: Ueberreuter.

Collier, Ruth B. and David Collier (1991) Shaping the Political Arena. Critical Junctures, the Labor Movement, and Regime Dynamics in Latin America. Princeton, NJ: Princeton Universtity Press.

Culpepper, Pepper D. (2011) Quiet Politics and Business Power. Corporate Control in Europe and Japan. Cambridge, NY: Cambridge University Press.

Der Standard (27.08.2003) Pühringer lebt gut mit Voest-Verkauf.

Die Presse (18.05.2008) AUA: Koalitionszwist und Privatisierung.

Die Presse (19.06.2008) Bartenstein für Verbund-Privatisierung.

Die Presse (12.07.2009) Privatisierung: Heiße Debatten um Schlussverkauf.

Die Zeit (26.08.2010) Der grüne Riese.

Elias, Norbert (1970) Was ist Soziologie. Weinheim/München: Juventa.

Ennser-Jedenastik, Laurenz (2013) “Die parteipolitische Besetzung von Spitzenfunktionen in österreichischen Staatsunternehmen: eine quantitative Analyse," Österreichische

Zeitschrift für Politikwissenschaft, 42(2):125-143.

Format (11.09.2003) Scharinger konkretisiert Voest-Pläne.

Grubelnik, Klaus (1998) Die rote Krake. Eine Bank erobert Österreich. Wien: Molden.

Hall, Peter A. (2006) "Stabilität und Wandel in den Spielarten des Kapitalismus." In: (Beckert, Jens, Bernhard Ebbinghaus, Anke Hassel and Philip Manow, eds.) Transformationen des Kapitalismus. Festschrift für Wolfang Streeck zum sechzigsten Geburtstag. Frankfurt a. M.: Campus, pp. 181-204. 
Hall, Peter A. and David Soskice (2001) “An Introduction to Varieties of Capitalism.” In: (Hall , Peter A. and David W. Soskice, eds.) Varieties of Capitalism. The Institutional Foundations of Comparative Advantage. Oxford: Oxford University Press, pp. 71-104.

Heemskerk, Eelke (2007) Decline of the corporate community: Network dynamics of the Dutch business elite. Amsterdam: Amsterdam University Press.

Hoffmann, Werner H. et al. (2011) "Stand der Unternehmensaufsicht in Österreich," Aufsichtsrat aktuell, 7(2):5-11.

Höpner, Martin and Lothar Krempel (2004) “The Politics of the German Company Network," Competition and Change, 8(4):339-356.

Hummell, Hans J. and Wolfgang Sodeur (2010) “Netzwerkanalyse.” In: (Wolf, Christof and Henning Best, eds.) Handbuch der sozialwissenschaftlichen Datenanalyse. Wiesbaden: VS Verlag für Sozialwissenschaften, pp. 575-603.

Katzenstein, Peter J. (1985) Small States in World Markets. Industrial Policy in Europe. Ithaca, NY: Cornell University Press.

Korom, Philipp (2013) “Politisierte Aufsichtsräte? Über die Entwicklung personeller Verflechtungen von Wirtschaft und Politik in Österreich (1989-2011)," forthcoming in Österreichische Zeitschrift für Soziologie.

Kriechbaumer, Robert (2008) Zeitenwende. Die SPÖ-FPÖ-Koalition 1983-1987 in der historischen Analyse, aus der Sicht der politischen Akteure und in Karikaturen von Ironimus. Wien: Böhlau.

Lehmbruch, Gerhard (1969) “Konkordanzdemokratie im Internationalen System.” In: (Czempiel, Ernst-Otto, ed.) Die anachronistische Souveränität. PVS-Sonderheft 1, Köln/ Opladen: Westdeutscher Verlag, pp. 139-163.

Leisch, Wilfried (2004) Du voest mir. Texte, Bilder, Fakten; das Buch wider das Vergessen zur Voest-Privatisierung. Wien: ÖGB-Verlag.

Meth-Cohn, Delia and Wolfgang C. Müller (1994) “Looking Reality into the Eye: The Politics of Privatization in Austria." In: (Wright, Vincent, ed.) Privatization in Western Europe. Pressures, Problems and Paradoxes. London: Pinter, pp. 160-179.

Mills, Charles W. (1956) The Power Elite. Oxford: Oxford University Press.

Mizruchi, Mark S. and Christopher Marquis (2006) “Interlocking Directorates." In: Beckert, Jens and Milan Zafirovsky, eds.) International Encyclopedia of Economic Sociology. London: Routledge, pp. 375-377.

Morawetz, Inge (1985) "Personelle Verflechtungen zwischen Großunternehmen und Banken in Österreich. Ergebnisse einer Netzwerkanalyse,” Österreichische Zeitschrift für Politikwissenschaft, 10(2):73-84.

Müller, Wolfgang C. (1988) "Privatizing in a Corporatist Economy: The Politics of Privatization in Austria," West European Politics, 11(4):101-116.

Nowotny, Ewald (1982) "Nationalized Industries as an Instrument of Stabilisation Policy: The Case of Austria," Management International Review, 53(1):41-56.

Obinger, Herbert (2006) “„Wir sind Voesterreicher”: Bilanz der ÖVP/FPÖ-Privatisierungspolitik in Austria.” In: (Tálos, Emmerich, ed.) Schwarz-Blau. Eine Bilanz des „Neu-Regierens.” Wien: Lit, pp. 154-169.

OECD. 2003. OECD Economic Surveys: Austria 2003. Paris: OECD Publishing.

Pfeffer, Jeffrey and Gerald R. Salancik (1978) The External Control of Organizations: A Ressource Dependence Perspective. New York: Harper \& Row.

Richardson, George B. (1972) “The Organization of Industry," The Economic Journal, 82(327):883-896. 
Scott, John (2000) Social Network Analysis. A Handbook. London: Sage.

Spiegel International (11.03.2009) Vulnerable in Vienna: Austria Feels Pinch of Eastern European Downturn.

Stark, David and Balazs Vedres (2012) "Political Holes in the Economy. The Business Network of Partisan Firms in Hungary," American Sociological Review, 77(5):700-722.

Stinchombe, Arthur L. (1990) "Weak Structural Data," Contemporary Sociology, 19(3):380-382. Stokman, Frans N., Rolf Ziegler and John Scott (eds.) (1985). Networks of Corporate Power. A Comparative Analysis of 10 Countries. Cambridge: Polity Press.

Stokman, Frans N., Jelle van der Knoop and Frans W. Wasseur (1988) "Interlocks in the Netherlands: Stability and Careers in the Period 1960-1980," Social Networks, 10(2): 183-208.

The Economist (04.09.2003). Don't sell our family silver! Austrians are still reluctant free-marketeers.

Teichova, Alice (1994) "Banking in Austria." In: (Pohl, Manfred, ed.) Handbook on the History of European Banks. Aldershot: Elgar, pp. 3-10.

Trappmann, Mark, Hans J. Hummell and Wolfgang Sodeur (2005) Strukturanalyse sozialer Netzwerke. Konzepte, Modelle, Methoden. Wiesbaden: VS Verlag für Sozialwissenschaften. Traxler, Franz (2007). "Austria." In: (Traxler, Franz and Gerhard Huemer, eds.) Handbook of Business Interest Associations, Firm Size and Governance. A Comparative Analytical Approach. London/New York: Routledge, pp. 39-63.

Treib, Oliver (2012) “Party Patronage in Austria: From Reward to Control.” In: (Kopecký, Petr, Peter Mair and Maria Spirova, eds.) Party Patronage and Party Government in European Democracies. Oxford: Oxford University Press, pp. 31-53.

Turnheim, Georg (2009) “Die verstaatlichten Unternehmen zwischen 1945 und 1955.” In: (Turnheim, Georg and Werner Clement, eds.) Österreichs Verstaatlichte. Die Rolle des Staates bei der Entwicklung der österreichischen Industrie von 1918 bis 2008. Wien: Manz, pp. 29-50.

Useem, Michael (1984) Inner circle. Large Corporations and the Rise of Business Political Activiety in the US and UK. Oxford: Oxford University Press.

Vitols, Sigurt (2004) "Negotiated Shareholder Value: The German Variant of an Anglo-American Practice," Competition and Change, 8(4):357-374.

Weber, Fritz (1994) “Austrian Nationalized Industry (1946-1976).” In: (Herbert Matis ed.) The Economic Development of Austria since 1870. Aldershot: Elgar, pp. 242-253.

Windolf, Paul (2002) Corporate networks in Europe and the United States. Oxford/New York: Oxford University Press.

Windolf, Paul (2006) "Unternehmensverflechtungen im organisierten Kapitalismus: Deutschland und USA im Vergleich 1896-1938," Zeitschrift für Unternehmensgeschichte, 51(2):191-222.

Windolf, Paul and Jürgen Beyer (1995) “Kooperativer Kapitalismus. Unternehmensverflechtungen im internationalen Vergleich," Kölner Zeitschrift für Soziologie und Sozialpsychologie, 47(1):1-36.

Windolf, Paul and Michael Nollert (2001) “Institutionen, Interessen, Netzwerke Unternehmensverflechtung im internationalen Vergleich," Politische Vierteljahresschrift, 42(1):51-78.

Ziegler, Rolf (1984) “Das Netz der Personen- und Kapitalverflechtungen deutscher und österreichischer Wirtschaftsunternehmen," Kölner Zeitschrift für Soziologie und Sozialpsychologie, 36(3): 557-584. 
Ziegler, Rolf (1987) "Besitzverhältnisse, Parteipräferenz und Personenverbindungen in der österreichischen Wirtschaft,” Österreichische Zeitschrift für Soziologie, 12(2):81-92.

Ziegler, Rolf, Donald Bender and Hermann Biehler (1985) “Austria Incorporated," In: (Stokman, Frans N., Rolf Ziegler and John Scott, eds.) Networks of Corporate Power. A Comparative Analysis of 10 Countries. Cambridge: Polity Press, pp. 73-90. 